\title{
Hydrothermal synthesis of fine oxide powders
}

\author{
SHIGEYUKI SŌMIYA* and RUSTUM ROY \\ Tokyo Institute of Technology, and Teikyo University of Science and Technology, 3-7-19 Seijo, Setagaya, \\ Tokyo 157-0066, Japan \\ Materials Research Laboratory, University Park, PA 16802, USA
}

MS received 29 August 2000

\begin{abstract}
This is a review and an overview on hydrothermal synthesis of fine oxide powders. The term hydrothermal today includes methods which involve water at pressures (from 1 atm-several kilobars) and high temperatures from $100-10,000$ C. Hydrothermal is one of the best methods to produce pure fine oxide powders. The authors describe (i) hydrothermal decomposition, (ii) hydrothermal metal oxidation, (iii) hydrothermal reaction, (iv) hydrothermal precipitation and hydrothermal hydrolysis, (v) hydrothermal electrochemical, (vi) reactive electrode submerged arc, (vii) hydrothermal microwave, (viii) hydrothermal sonochemical, etc and also ideal and real powders.
\end{abstract}

Keywords. Hydrothermal; synthesis; fine powders; oxide powders.

\section{Introduction to powder preparation}

Inorganic powders are among the most important factors in many fields of materials such as ceramics, catalysts, medicines, food, etc. There are many papers and books related to powders preparation by many authors (Veale 1972; Kato and Yamaguchi 1983; Vincenzini 1983; Brinker et al 1984; Johnson Jr. 1987; Messing et al 1987; Segal 1989; Ganguli and Chatterjee 1997; Chemical Society of Japan 1985, for examples). Powder preparation is a most important step among the processing steps in ceramics. Therefore there are many reports on this topic worldwide, some of these being mentioned here. Table 1 (Sōmiya and Akiba 1999) shows varieties of preparative methods for fine ceramic powders.

\section{Hydrothermal synthesis}

The term 'hydrothermal' came from the earth sciences, where it implied a regime of high temperatures and water pressures. Table 2 (Morey 1953; Walker 1953; Eitel 1966; Laudise 1970; Lobachev 1971; Sōmiya 1983, 1989, 1994; Stambaugh 1983; Demianets et al 1984; Rabenau 1985; Brice 1986; Dawson 1988; Byrappa 1991; Rouxed et al 1994) shows the place of hydrothermal synthesis among others. Major differences between hydrothermal processing and other technologies are shown in table 3 (Dawson 1988; Segal 1989; Johnson Jr. 1987; Sōmiya and Akiba 1999). For typical H-T research one needs a

\footnotetext{
*Author for correspondence
}

high temperature, high-pressure apparatus called 'autoclaves' or 'bombs'. A great deal of early experimental work was done using the Morey bomb (Morey 1953) and Tuttle-Roy test tube bomb (Tem-Press) which are shown in figures 1 and 2 respectively. Hydrothermal synthesis involves $\mathrm{H}_{2} \mathrm{O}$ both as a catalyst and occasionally as a component of solid phases in the synthesis at elevated temperature $\left(>100^{\circ} \mathrm{C}\right)$ and pressure ( $>$ a few atmosphere). At present, one can get many kinds of autoclaves to cover different $p-t$ ranges and volumes. In the US there are 3 types of companies. (i) Tem-Press: They are the best source for research vessels of all kinds including test tube bombs and gas intensifiers for specialized gases, $\mathrm{A}, \mathrm{H}_{2}$, $\mathrm{O}_{2}, \mathrm{NH}_{3}$, etc. (ii) Autoclave Engineers: They make a complete line of lab-scale valves, tubing, collars, all fittings for connections, etc and they also make very large autoclaves $(1-3 \mathrm{~m})$ for quartz and other chemical processes and (iii) Parr Instrument: They make simple, lowpressure, low-temperature $\left(300^{\circ} \mathrm{C}, 1000\right.$ bars) laboratory scale type of autoclaves, $50 \mathrm{ml}-11$ for low temperature reactions, including vessels lined Teflon, etc.

For hydrothermal experiments the requirements for starting materials are (i) accurately known composition, (ii) as homogeneous as possible, (iii) as pure as possible and (iv) as fine as possible, etc.

\subsection{Some results in different categories (Hydrothermal decomposition)}

2.1a Ilmenite (Ismail and Somiya 1983): Ilmenite is a very stable mineral, with a composition of $\mathrm{FeTiO}_{3}$. Extraction of $\mathrm{TiO}_{2}$ from such ores has potential. $10 \mathrm{~m}$ 
$\mathrm{KOH}$ or $10 \mathrm{M} \mathrm{NaOH}$ mixed with ilmenite in the ratio $5: 3$ (of ilmenite to water) was reacted under hydrothermal conditions at $500^{\circ} \mathrm{C}, 300 \mathrm{~kg} / \mathrm{cm}^{2}$. Ilmenite was decomposed completely after $63 \mathrm{~h}$. If the ratio of ilmenite to water was $5: 4$, at the same condition, $39 \mathrm{~h}$ was necessary to decompose the ilmenite. Reactions were as follows: In the case of $\mathrm{KOH}$ solution,

$$
\begin{aligned}
& \mathrm{FeTiO}_{3}+\mathrm{H}_{2} \mathrm{O} \rightarrow \mathrm{Fe}_{3-x} \mathrm{O}_{4}+\mathrm{TiO}_{2}+\mathrm{H}_{2}, \\
& \mathrm{FeTiO}_{3}+\mathrm{KOH} \rightarrow \mathrm{K}_{2} \mathrm{O}\left(\mathrm{TiO}_{2}\right)_{n}+\mathrm{H}_{2} \mathrm{O} \quad n=4 \text { or } 6 .
\end{aligned}
$$

\subsection{Hydrothermal metal oxidation}

2.2a Zr metal (Yoshimura et al 1984): 10-50 g Zr metal powder was reacted with water to form the oxide.

$$
\mathrm{Zr}+\mathrm{H}_{2} \mathrm{O} \stackrel{300^{\circ}}{\longrightarrow} \mathrm{ZrO}_{2}+\mathrm{ZrH}_{x} \stackrel{400^{\circ}}{\longrightarrow} \mathrm{ZrO}_{2}+\mathrm{H}_{2}
$$

At $300^{\circ} \mathrm{C}$ under $98 \mathrm{MPa}, \mathrm{ZrO}_{2}$ and $\mathrm{ZrH}_{x}$ appeared. Above

Table 1. Methods for fine ceramic powders.

\begin{tabular}{ll}
\hline 1) Mechanical & a) Ball milling \\
(powder mixing) & b) Attrition milling \\
c) Vibration milling \\
2) Thermal decomposition & a) Heating (evaporation) \\
& b) Spray drying \\
c) Flame spraying \\
d) Plasma spraying \\
e) Vapour phase (CVD) \\
f) Freeze drying (cryochemical) \\
g) Hot kerosene drying \\
h) Hot petroleum drying \\
i) Combustion \\
j) Laser beam \\
k) Electron beam \\
1) Sputtering \\
3) Precipitation or & a) Neutralization and precipitation \\
hydrolysis & b) Homogeneous precipitation \\
& c) Coprecipitation \\
d) Salts solution
\end{tabular}

4) Hydrothermal Precipitation (coprecipitation)
b) Crystallization
c) Decomposition
d) Oxidation
e) Synthesis
f) Electrochemical
g) Mechanochemical
h) RESA (reactive electrode
submerged arc)

Hydrothermal + microwave

Hydrothermal + ultrasonic

5) Melting and rapid

quenching $400^{\circ} \mathrm{C}$ under $98 \mathrm{MPa}, \mathrm{ZrH}_{x}$ disappeared and only $\mathrm{ZrO}_{2}$ was formed. Figures 3 and 4 show $\mathrm{ZrO}_{2}$ powders formation by hydrothermal oxidation.

2.2b Al metal (Toraya et al 1984): Al metal was reacted with water under $100 \mathrm{MPa}$ between $200^{\circ} \mathrm{C}$ and $700^{\circ} \mathrm{C}$ for 0 to $6 \mathrm{~h}$. $\mathrm{AlOOH}$ appeared between $100^{\circ} \mathrm{C}$ and $\alpha-\mathrm{Al}_{2} \mathrm{O}_{3}$ between $500^{\circ} \mathrm{C}$ and $700^{\circ} \mathrm{C}$.

2.2c Ti metal (Yoshimura et al 1987): Ti metal powder reacted with water in the ratio $1: 2$ in a gold capsule, heated under hydrothermal condition of $100 \mathrm{MPa}$ for $3 \mathrm{~h}$ up to $700^{\circ} \mathrm{C}$. Figure 5 shows the results.

\subsection{Hydrothermal reactions}

There are many papers, for example (Tani et al 1981, 1983; Nishizawa et al 1982; Yoshimura and Sōmiya

Table 2. Hydrothermal synthesis.

\begin{tabular}{l}
\hline Hydrothermal crystal growth \\
Hydrothermal treatment \\
Hydrothermal alternation \\
Hydrothermal dehydration \\
Hydrothermal extraction \\
Hydrothermal reaction sintering \\
Hydrothermal sintering \\
Corrosion reaction \\
Hydrothermal oxidation \\
Hydrothermal precipitation- \\
hydrothermal crystallization \\
Hydrothermal decomposition \\
Hydrothermal hydrolysis- \\
hydrothermal precipitation \\
Hydrothermal electrochemical reaction \\
Hydrothermal mechanochemical reaction \\
Hydrothermal + ultrasonic \\
Hydrothermal + microwave
\end{tabular}

Table 3. Major differences of powders and processing between hydrothermal and other technology for powder preparation based on studies mainly by Dawson, Segal, Johnson Jr. and Sōmiya.

1) Powders are formed directly from solution

2) Powders are anhydrous, crystalline or amorphous. It depends on producing of hydrothermal powder temperature

3) It is able to control particle size by hydrothermal temperature

4) It is able to control particle shape by starting materials

5) It is able to control chemical, composition, stoichiometry, etc

6) Powders are highly reactive in sintering

7) Many cases, powders do not need calcination

8) Many cases, powders do not need milling process 
1984; Komarneni et al 1986; Haberko et al 1991, 1995) on hydrothermal reactions. $\mathrm{ZrCl}_{4}$ solution with $\mathrm{NH}_{4} \mathrm{OH}$ formed hydrated zirconia. Then it was washed with distilled water and dried for $48 \mathrm{~h}$ at $120^{\circ} \mathrm{C}$. This starting material with various solutions was put into a $\mathrm{Pt}$ or $\mathrm{Au}$ tube under $100 \mathrm{MPa}$ at $300^{\circ} \mathrm{C}$ for $24 \mathrm{~h}$. The results are

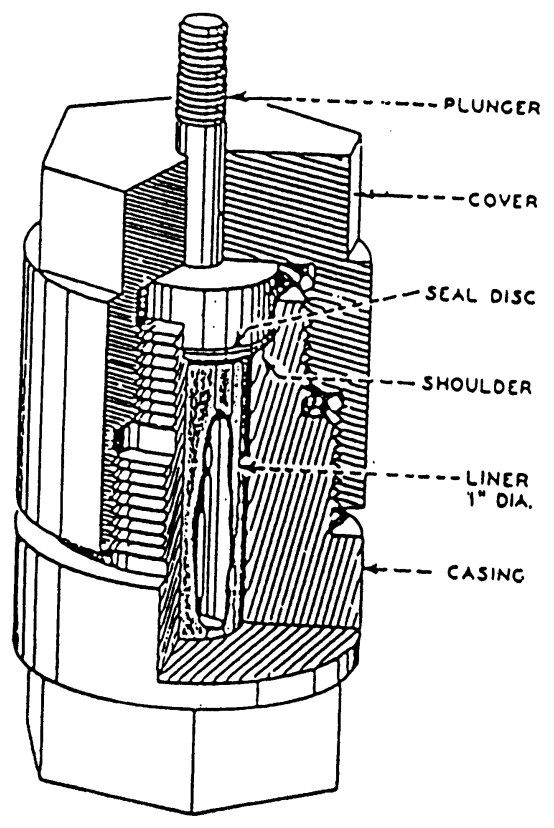

Figure 1. Autoclave with flat plate closure (after Morey 1953).

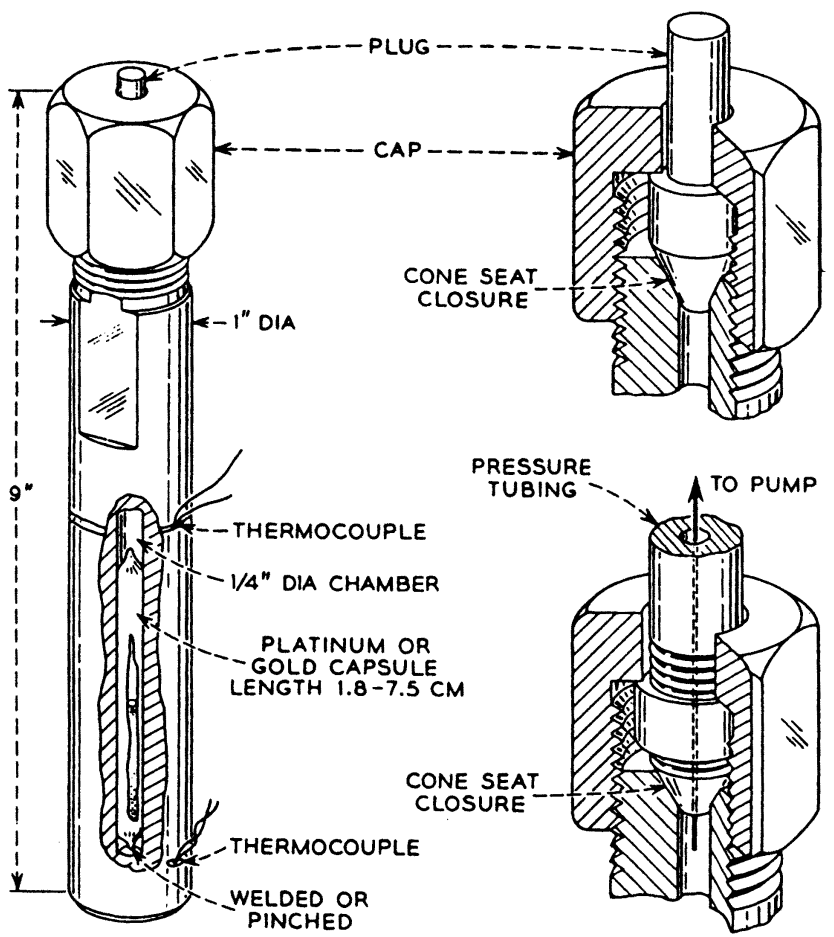

Figure 2. Reaction vessel with a cold-cone seat closure (Tem-press). shown in table 4 (Tani et al 1981, 1983). Clearly we have excellent $\mathrm{ZrO}_{2}$ less than $40 \mathrm{~nm}$ (figure 6).

\subsection{Hydrothermal precipitation or hydrothermal hydrolysis}

2.4a Alumina: One of the industrial application of this process is ordinary alumina production. In figure 7 is shown the Bayer process (Riman 1999).

2.4b Zirconia: Hydrothermal homogeneous precipitation is one of the best methods to produce zirconia powders. One Japanese company attempted to produce zirconia powders by this method. The process, properties of the powders and microstructure of the sintered body are shown in table 5 and figures 8, 9 and 10 respectively (Hishinuma et al 1988; Sōmiya et al 1991).

\subsection{Hydrothermal electrochemical method}

Figure 11 shows an apparatus of the hydrothermal electrochemical method. For preparing $\mathrm{BaTiO}_{3}$, Ti and $\mathrm{Pt}$

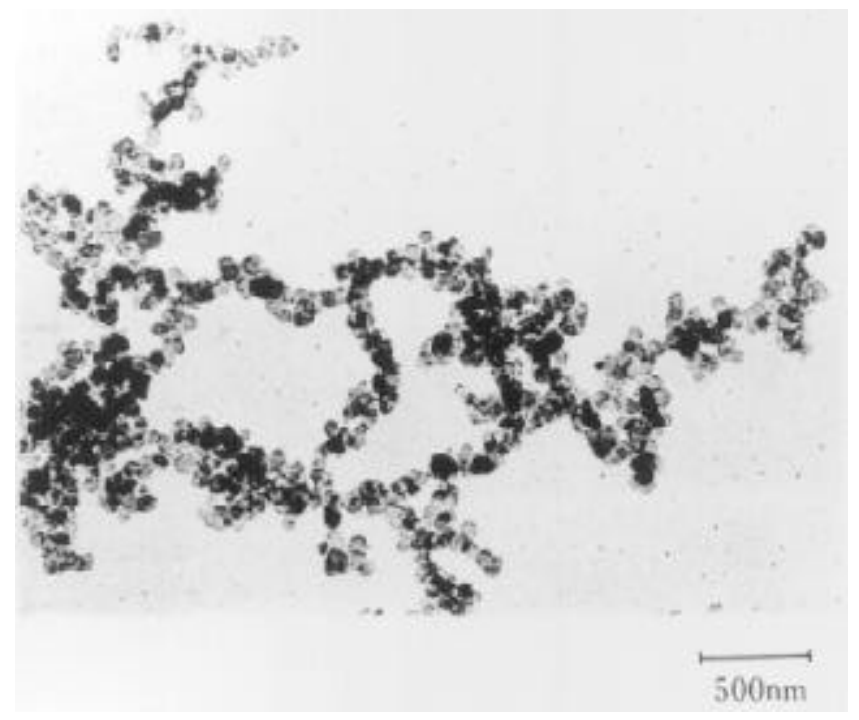

Figure 3. TEM of zirconia powder by hydrothermal oxidation $\left(100 \mathrm{MPa} 500^{\circ} \mathrm{C} 3 \mathrm{~h} \mathrm{Zr} / \mathrm{O}=0 \cdot 33\right)$.

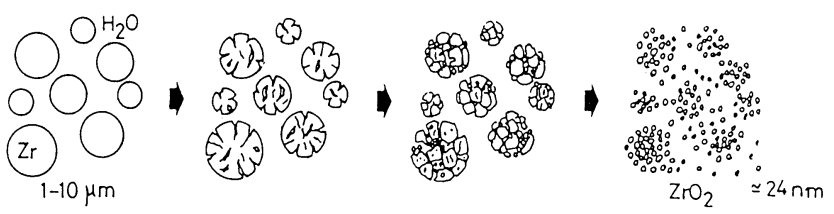

Figure 4. Schematic illustration of hydrothermal oxidation of zirconia powder. 
plates were used as working electrode of anode and counter electrode of cathode respectively. Solution of Ba-nitrate $0 \cdot 1 \mathrm{~N}$ or $0.5 \mathrm{~N}$ and temperature up to $250^{\circ} \mathrm{C}$ were used for the experiment. Current density was $100 \mathrm{~mA} / \mathrm{cm}^{2}$. Under these conditions we were able to get $\mathrm{BaTiO}_{3}$ powder. Powder of $\mathrm{BaTiO}_{3}$ by this process is shown in figure $12 . \mathrm{ZrO}_{2}$ was also produced by this method. In the case of $\mathrm{ZrO}_{2}, \mathrm{Zr}$ plates were used (Yoo et al 1988; Yoshimura et al 1989a).

\subsection{Reactive electrode submerged arc (RESA)}

RESA (Kumar and Roy 1988, 1989) is totally a new process for making powders. RESA provides access to extremely high temperatures $\left(\neq 10,000^{\circ} \mathrm{K}\right)$ with 1 atm $\mathrm{H}_{2} \mathrm{O}$ (possibly more in the nano-environment) pressures. It allows one to change liquids very easily. Figure 13 shows the apparatus and figure 14 some resulting powders.

Table 4. Phases present and crystallite size of products by hydrothermal reaction at $100 \mathrm{MPa}$ for $24 \mathrm{~h}$.

\begin{tabular}{lccc}
\hline & & \multicolumn{2}{c}{ Average crystallite size (nm) } \\
\cline { 3 - 4 } Mineralizer & $\begin{array}{c}\text { Temperature } \\
\left({ }^{\circ} \mathrm{C}\right)\end{array}$ & $\begin{array}{c}\text { Tetragonal } \\
\mathrm{ZrO}_{2}(\mathrm{~nm})\end{array}$ & $\begin{array}{c}\mathrm{Monoclinic} \\
\mathrm{ZrO}_{2}(\mathrm{~nm})\end{array}$ \\
\hline $\mathrm{KF}(8 \mathrm{wt} \%)$ & 200 & Not detected & 16 \\
$\mathrm{KF}(8 \mathrm{wt} \%)$ & 300 & Not detected & 20 \\
$\mathrm{NaOH}(30 \mathrm{wt} \%)$ & 300 & Not detected & 40 \\
$\mathrm{H}_{2} \mathrm{O}$ & 300 & 15 & 17 \\
$\mathrm{LiCI}(15 \mathrm{wt} \%)$ & 300 & 15 & 19 \\
$\mathrm{KBi}(10 \mathrm{wt} \%)$ & 300 & 13 & 15 \\
\hline
\end{tabular}

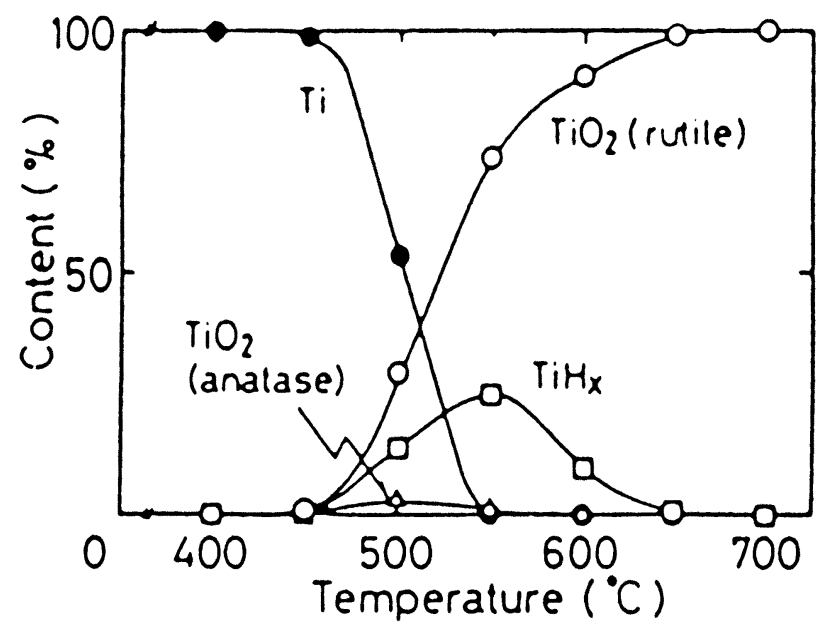

Figure 5. Variation of amount of products with temperature by the hydrothermal oxidation of $\mathrm{Ti}$ in the closed system under $100 \mathrm{MPa}$ for $3 \mathrm{~h}$.

\subsection{Hydrothermal mechanochemical process}

$\mathrm{Ba}(\mathrm{OH})_{2}$ and $\mathrm{FeCl}_{3}$ were used as starting materials. The precipitate was crystallized hydrothermally in an apparatus combined with an attritor and ambient water pressure. The starting solutions with the precipitate and stainless

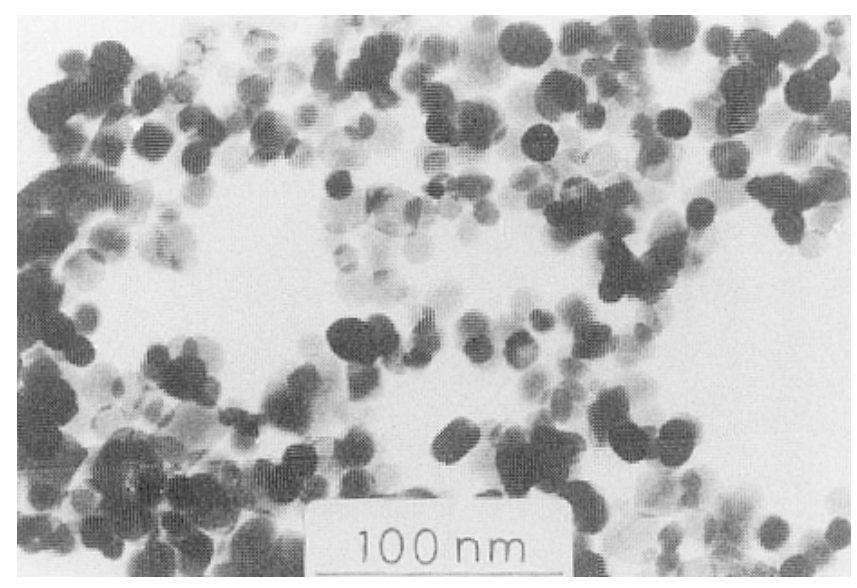

Figure 6. TEM of monoclinic zirconia powder by hydrothermal reaction under $400^{\circ} \mathrm{C}, 100 \mathrm{MPa}$ for $24 \mathrm{~h}$ using $8 \mathrm{wt} \%$ KF solution.

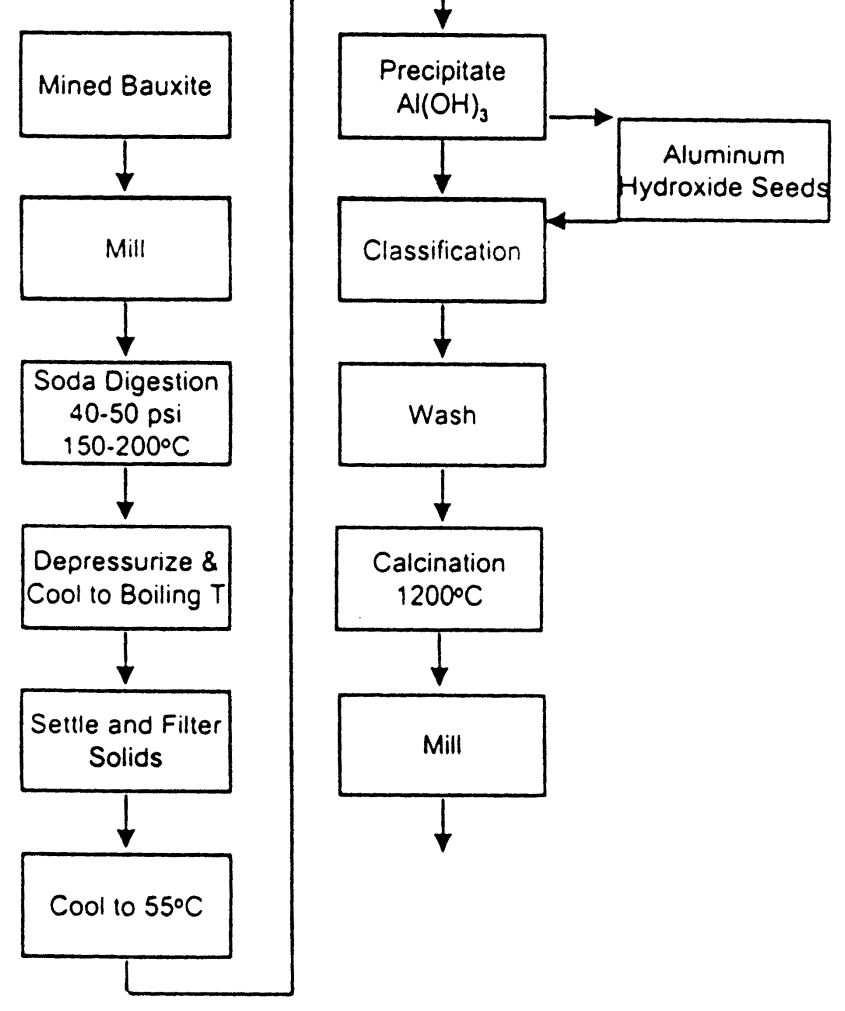

Figure 7. Bayer process (Riman). 


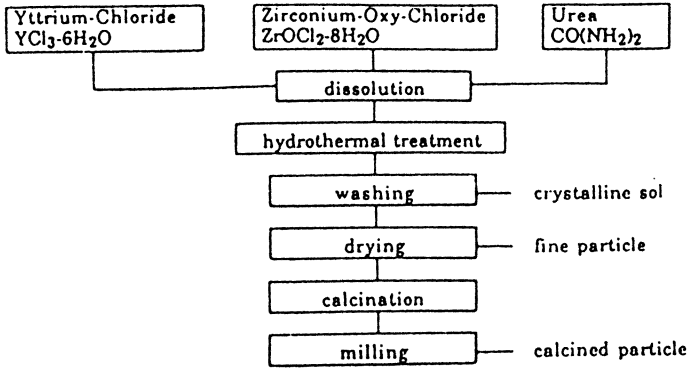

Figure 8. $\mathrm{ZrO}_{2}$ by hydrothermal homogeneous precipitation process.

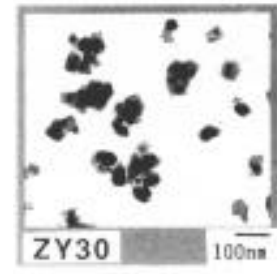

$\mathrm{YO}_{3} 5.2 \mathrm{~ms}$ $2 \mathrm{ZO}_{2} 94.7 \mathrm{wts}$

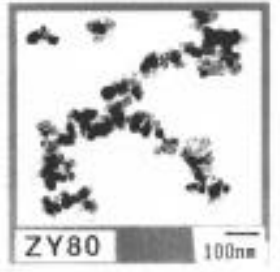

$\mathrm{Y}_{2} \mathrm{O}_{3}, 13.9 \mathrm{wt} \%$ $\mathrm{ZrO}_{2} 86.0 \mathrm{wt} \%$

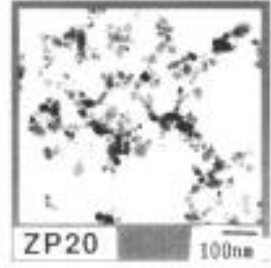

$\mathrm{ZrO}_{2}>999 \mathrm{wt} \%$
Figure 9. TEM of hydrothermal homogeneous precipitation zirconia powder (Chichibu Onoda Cement Corp.). steel balls of $5 \mathrm{~mm}$ dia. were set in a teflon beaker. The teflon propellor was rotated in the beaker under $200^{\circ} \mathrm{C}$ and $2 \mathrm{MPa}$. Rotating speed of the propellor was from 0 to $107 \mathrm{rpm}$. The number of balls was 200, 500 and 700. Xray diffraction profiles are shown in figure 15 (Yoshimura et al 1989b).

\subsection{Hydrothermal microwave process}

Komarneni and his cowokers have developed this process in a long series of papers (Komarneni et al 1992, 1993, 1994, 1995). Hydrothermal microwave treatment of $0.5 \mathrm{M}$ $\mathrm{TiCl}_{4}$ was done in $1 \mathrm{M} \mathrm{HCl}$ to form $\mathrm{TiO}_{2}$. The system operated at a $2.45 \mathrm{GHz}$ frequency. The vessel is Teflon and it is able to operate up to $200 \mathrm{psi}$. The parameters used are temperature, pressure, time, concentration of metal solution, $\mathrm{pH}$, etc. The key result being crystallization reactions which lead to faster kinetics by one or two orders of magnitude compared to the conventional hydrothermal processing.

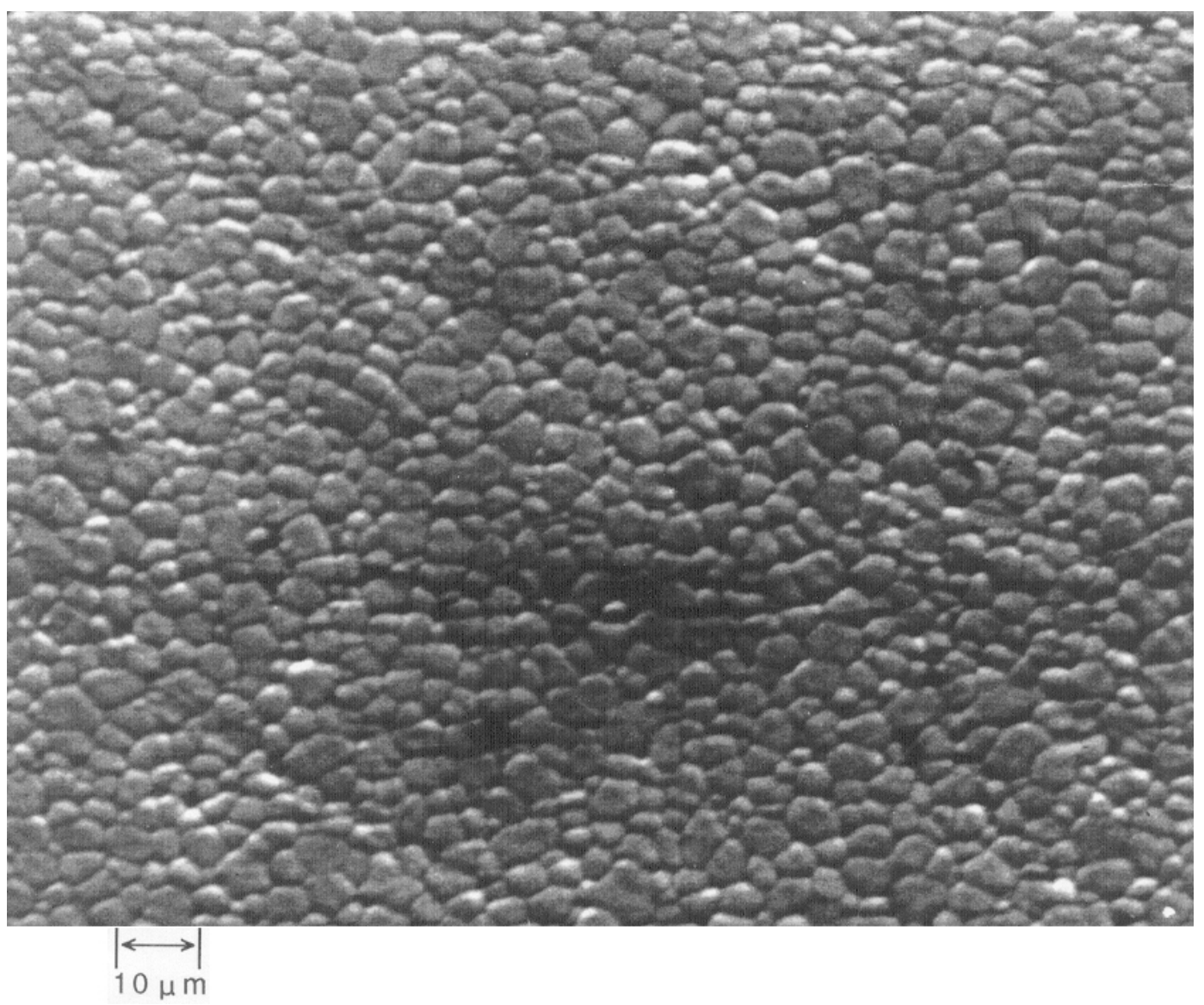

Figure 10. TEM of the zirconia sintered at $1400^{\circ} \mathrm{C}$ for $2 \mathrm{~h}$. 
Table 5. Typical characteristics of $\mathrm{ZrO}_{2}$ powders by hydrothermal homogeneous precipitation.

\begin{tabular}{|c|c|c|c|}
\hline Powder & ZY30 & ZY80 & $\mathrm{ZP} 20$ \\
\hline \multicolumn{4}{|l|}{ Chemical composition } \\
\hline $\mathrm{ZrO}_{2}(\mathrm{wt} \%)$ & $94 \cdot 7$ & $86 \cdot 0$ & $>99.9$ \\
\hline $\mathrm{Y}_{2} \mathrm{O}_{3}$ & $5 \cdot 2$ & $13 \cdot 9$ & - \\
\hline $\mathrm{Al}_{2} \mathrm{O}_{3}$ & $0 \cdot 010$ & $0 \cdot 010$ & 0.005 \\
\hline $\mathrm{SiO}_{2}$ & $0 \cdot 010$ & $0 \cdot 010$ & 0.005 \\
\hline $\mathrm{Fe}_{2} \mathrm{O}_{3}$ & $0 \cdot 005$ & 0.005 & 0.005 \\
\hline $\mathrm{Na}_{2} \mathrm{O}$ & $0 \cdot 001$ & $0 \cdot 001$ & $0 \cdot 001$ \\
\hline $\mathrm{Cl}^{-}$ & $<0.01$ & $<0.01$ & $<0.01$ \\
\hline Ignition loss & 1.5 & 1.5 & $8 \cdot 0$ \\
\hline Crystallite size (nm) & 22 & 22 & 20 \\
\hline Average particle size ${ }^{\dagger}(\mu \mathrm{m})$ & $0 \cdot 5$ & $0 \cdot 5$ & 1.5 \\
\hline Specific surface area $\left(\mathrm{m}^{2} / \mathrm{g}\right)$ & 20 & 25 & 95 \\
\hline Sintered specimens & $1400^{\circ} \mathrm{C} \times 2 \mathrm{~h}$ & $1500^{\circ} \mathrm{C} \times 2 \mathrm{~h}$ & \\
\hline Bulk density $\left(\mathrm{g} / \mathrm{cm}^{3}\right)$ & 6.05 & $5 \cdot 85$ & \\
\hline Bending strength ${ }^{\dagger \dagger \dagger}(\mathrm{MPa})$ & 1000 & 300 & \\
\hline Fracture toughness ${ }^{\dagger \dagger \dagger}\left(\mathrm{MPam}^{1 / 2}\right)$ & $6 \cdot 0$ & $2 \cdot 5$ & \\
\hline Vicker's hardness (GPa) & $12 \cdot 5$ & $11 \cdot 0$ & \\
\hline $\begin{array}{l}\text { Thermal expansion } \\
\qquad 20 \sim 1000^{\circ} \mathrm{C}\left(\times 10^{-6} /{ }^{\circ} \mathrm{C}\right)\end{array}$ & $11 \cdot 0$ & $10 \cdot 6$ & \\
\hline
\end{tabular}

†'Photo sedimentation method; ${ }^{\ddagger}$ B.E.T. method $\left(\mathrm{N}_{2}\right)$; ${ }^{\dagger \dagger}$ 3-Point bending method; and ${ }^{\dagger \dagger \dagger}$ M.I. method.

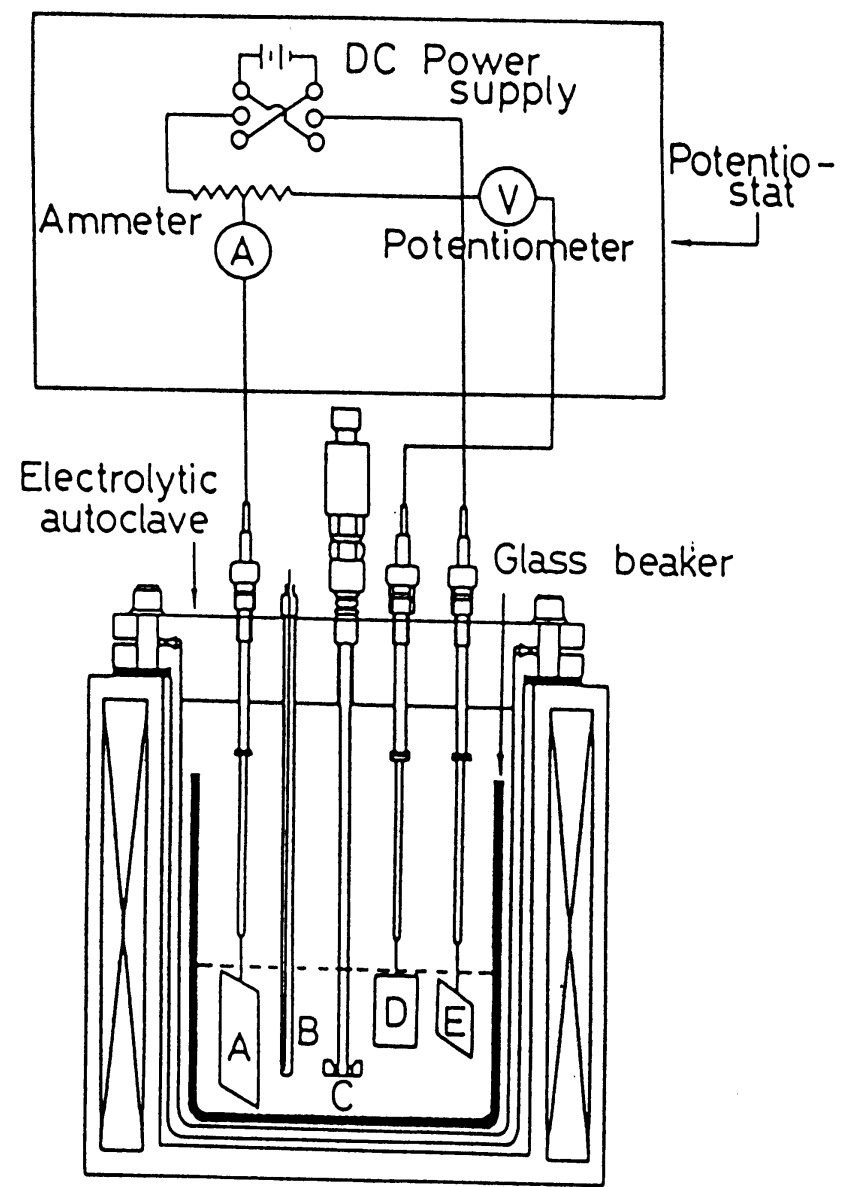

Figure 11. Schematic illustration of the electrochemical cell and circuit arrangements for anodic oxidation of Ti metal plate under hydrothermal condition. (A) Counter electrode (Pt plate), cathode, (B) thermocouple, (C) stirrer, (D) reference electrode (Pt plate) and (E) working electrode (Ti plate), anode.
Table 6. Ideal powder.

1. Fine powder less than $1 \mu \mathrm{m}$

2. Soft or no agglomeration

3. Narrow particle size distribution

4. Morphology, sphere

5. Chemical composition controllable

6. Microstructure controllable

7. Uniformity

8. Free flowing

9. Less defects, dense particle

10. Less stress

11. Reactivity, sinterability

12. Crystallinity

13. Reproducibility

14. Process controllable

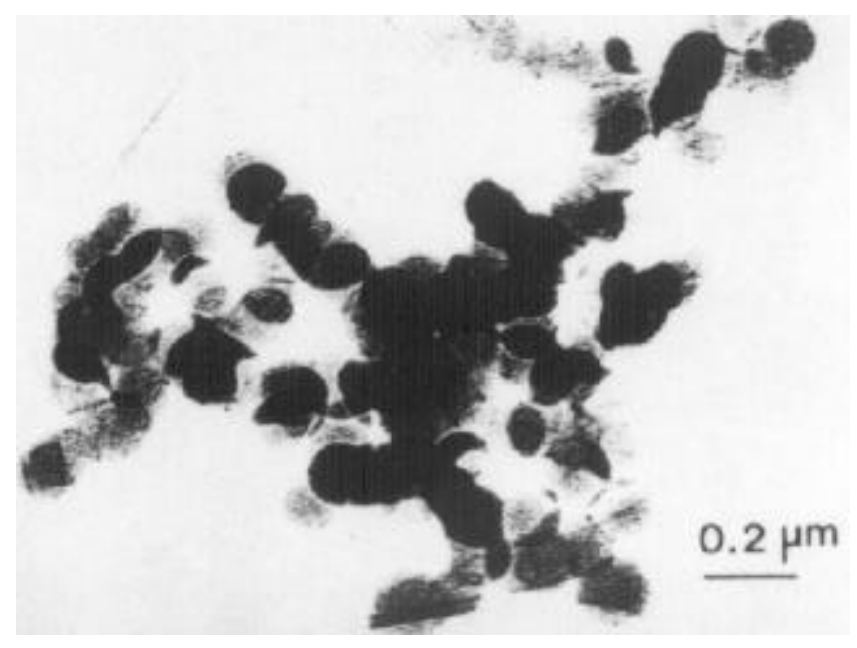

Figure 12. TEM of $\mathrm{BaTiO}_{3}$ powders prepared by hydrothermal electrochemical method $\left(250^{\circ} \mathrm{C}, 0 \cdot 5 \mathrm{~N} \mathrm{Ba}\left(\mathrm{NO}_{3}\right)_{2}\right.$, Ti plate used $)$. 


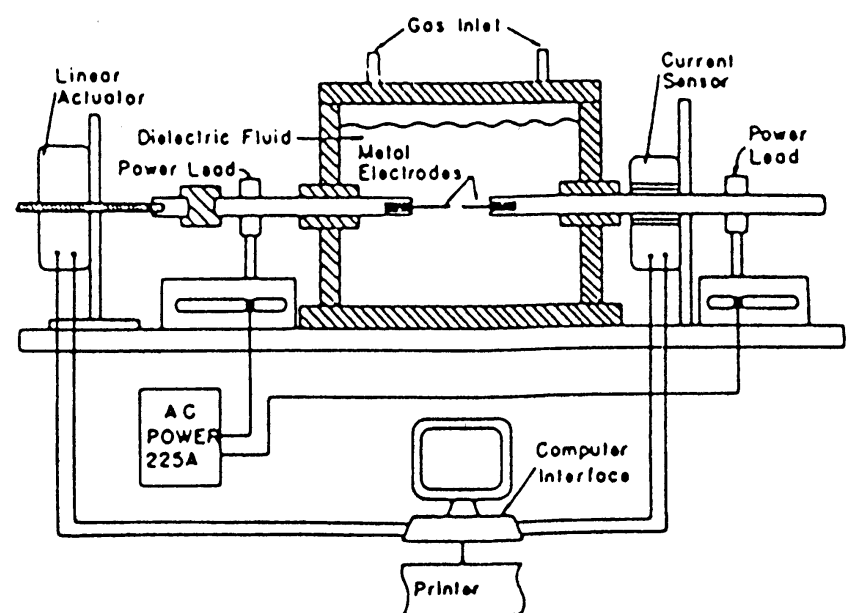

Figure 13. Schematic of microprocessor-controlled RESA apparatus for fine-powder preparation (Kumar and Roy).

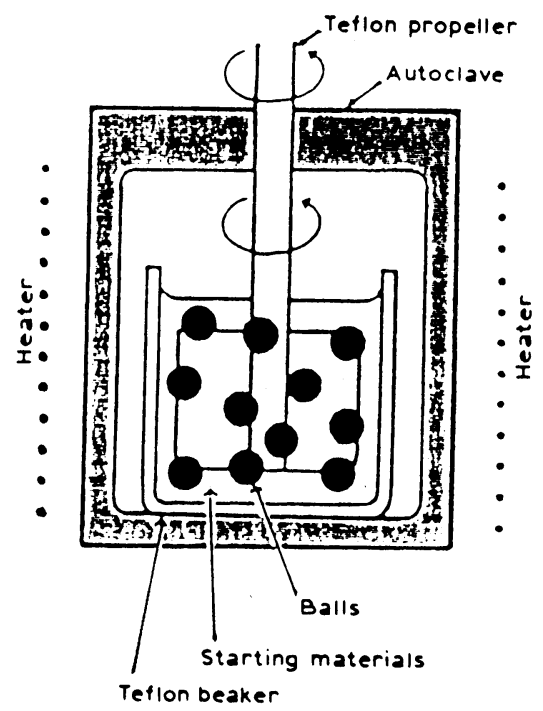

Figure 14. Experimental apparatus for hydrothermal mechanochemical reactions.

\subsection{Hydrothermal sonochemical method}

Ultrasonic waves are often used in analytical chemistry for dissolving powder to make solution (Milia 1995). Hydrothermal sonochemical method is a new field for synthesis of materials.

\section{Ideal powders and real powders}

Preparation of ideal powders and real powders by hydrothermal processing are shown in tables 6 and 7 . Hydrothermal powders are close to ideal powders (Sōmiya 1994).

\section{Conclusion}

This paper describes hydrothermal fine powders. This hydrothermal fine powders are very close to the ideal fine powder.

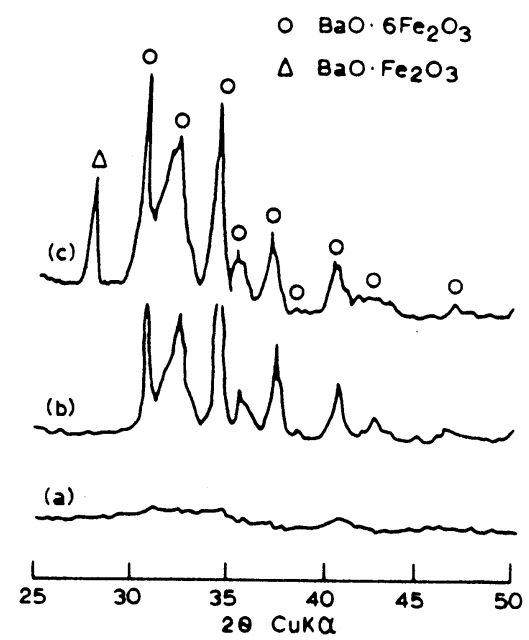

Figure 15. X-ray diffraction profiles of (a) starting materials, (b) material fabricated at $200^{\circ} \mathrm{C}$ under $2 \mathrm{MPa}$ for $4 \mathrm{~h}$ without rotation and (c) material fabricated at $200^{\circ} \mathrm{C}$ for $4 \mathrm{~h}$ using 200 balls $37 \mathrm{rpm}$.

Table 7. Characteristics of hydrothermal powders.

Grain size: fine grain less than $1 \mu \mathrm{m}$

Coagulation: No or weak agglomeration

Crystallinity: Single crystal in general. It depends on preparation temperature

Flow ability: forming is good

Homogeneity: good

Sinterability: good

Pores in grain: no pore

Particle size distribution: narrow

Able to synthesize low temperature form and/or metastable form

Able to make composites like organic and inorganic mixture

Able to make a material which has a very high vapour pressure

\section{References}

Autoclave Engineers, Catalogue

Brice L C 1986 Hydrothermal growth, crystal growth processes (Glasgow: Blackie Halsted Press) p. 194

Brinker C J et al (eds) 1984 Better ceramics through chemistry I (Amsterdam: North Holland) p. 398

Byrappa K (ed.) 1991 Hydrothermal growth of crystals, progress in crystal growth and characterization of materials (Oxford: Pergamon Press)

Chemical Society of Japan (ed.) 1985 Ultral fine powders-Science and application (Tokyo: Gakkai Publication Centre) p. 211

Dawson W J 1988 Am. Ceram. Soc. Bull. 671973

Demianets L N et al 1984 Growth and synthesis in hydrothermal solutions, Modern crystallography III, Crystal growth (eds) A A Chernov et al (Berlin: Springer-Verlag) p. 380

Eitel W 1966 Silicate science (New York: Academic Press) Vol. IV p.149

Ganguli D and Chatterjee M 1997 Ceramic powder prepara- 
tion: A handbook (The Netherlands: Kluwer Academic Publishers) p. 221

Haberko K et al 1991 J. Am. Ceram. Soc. 742622

Haberko K et al 1995 J. Am. Ceram. Soc. 783397

Hishinuma K et al 1988 Advances in ceramics, Science and technology of zirconia III (Westerville, Ohio: Am. Ceram. Soc.) Vol. 24 p. 201

Ismail M G M U and Somiya S 1983 Proc. Int. symp. on hydrothermal reactions (Tokyo: Gakujutsu Bunken Fukyu Kai) p. 669

Johnson Jr. D W 1987 Advances in ceramics (eds) G L Messing et al (Westerville, Ohio: Am. Ceram. Soc.) Vol. 21 p.3

Kato A and Yamaguchi T 1983 New ceramic powder handbook (Tokyo: Tokyo Science Forum) p. 558

Komarneni S et al 1986 Advanced ceramic materials (Westerville, Ohio: Am. Ceram. Soc.) 1 p. 87

Komarneni S et al 1992 Mater. Res. Bull. 271393

Komarneni S et al 1993 J. Mater. Res. 83176

Komarneni S et al 1994 J. Mater. Chem. 41903

Komarneni S et al 1995 J. Mater. Res. 101687

Kumar A and Roy R 1988 J. Mater. Res. 31373

Kumar A and Roy R 1989 J. Am. Ceram. Soc. 72354

Laudise R A 1970 Hydrothermal growth, The growth of single crystals (New Jersey: Prentice Hall Inc.) p. 275

Lobachev A N (ed.) 1971 Hydrothermal synthesis of crystals (New York: Consultant Bureau) p. 152

Messing G L et al (eds) 1987 Ceramic powder science, Advances in ceramics (Westerville, Ohio: Am. Ceram. Soc.) Vol. 21 p. 825

Milia A M 1995 Sonochemistry and cavitation (Luxemburg: Gordon and Breach Publishers) p. 543

Morey G W 1953 J. Am. Ceram. Soc. 36279

Nishizawa H et al 1982 J. Am. Ceram. Soc. 65343

Parr Instrument Co. Catalogue

Rabenau A 1985 Angew. Chem. Int. Ed. Engl. 241026

Riman R 1999 The textbook ceramic powder technologies, 101 st Annual meeting (Westerville, Ohio: Am. Ceram. Soc.)

Rouxed J et al 1994 Soft chemistry routes to new materialsChemie douce (Switzerland: Trans. Tech.) p. 394

Sōmiya S (ed.) 1983 Proc. first int. symp. on hydrothermal reactions (Tokyo: Gakujutsu Bunken Fukyu Kai) p. 965
Sōmiya S (ed.) 1989 Hydrothermal reactions for material science and engineering, An overview of research in Japan (London: Elsevier Applied Science) p. 505

Sōmiya S 1994 Advanced materials 1993, VI Trans. MRS-Japan frontiers in materials science and engineering (Amsterdam: Elsevier Science BV) Vol. 19B p. 1105

Sōmiya S and Akiba T 1999 Trans. MRS-Tokyo, Japan 24 531

Sōmiya S et al 1991 Hydrothermal growth of crystals, Progress in crystal growth and characterization of materials (Oxford: Pergamon Press) Vol. 21 p. 195

Segal D 1989 Chemical synthesis of advanced ceramic materials (Cambridge: Cambridge University Press) p. 182

Stambaugh E P 1983 New/improved ceramic, magnetic and electronic oxides by hydrothermal processing, 85th Annual meeting (Chicago, Il: Am. Ceram. Soc.)

Tani E et al 1981 J. Am. Ceram. Soc. 64 C-181

Tani E et al 1983 J. Am. Ceram. Soc. 6611

Tem-Press Div. Leco Corp. Catalogue

Toraya $\mathrm{H}$ et al 1984 Advances in ceramics, Science and technology of zirconia II (Westerville, Ohio: Am. Ceram. Soc.) Vol. 12 p. 806

Veale C R 1972 Fine powder preparation, Properties and uses (London: Applied Science Publishers) p. 147

Vincenzini P (ed.) 1983 Ceramic powders (Amsterdam: Elsevier Scientific Co.) p. 1025

Walker A C 1953 J. Am. Ceram. Soc. 36250

Yoo S E et al 1988 Sintering 87 (eds) S Sōmiya et al (London: Elsevier Applied Science) p. 108

Yoshimura M and Sōmiya S 1984 Rep. Res. Lab. Eng. Mat. Tokyo Inst. of Technology No. 9 p. 53

Yoshimura M et al 1981 Preparation of zirconia fine powders by the reactions between zirconium metal and high temperature-high pressure solutions, 8th AIRAPT conf. 1988 (Sweden: 8th AIRAPT Committee) p. 793

Yoshimura M et al 1987 Rep. Res. Lab. Eng. Mat. Tokyo Inst. of Technology No. 12 p. 59

Yoshimura M et al 1989a Rep. Res. Lab. Eng. Mat. Tokyo Inst. Technology No. 14 p. 21

Yoshimura M et al 1989b J. Ceram. Soc. Jap. Int. Ed. 9714 